\title{
Evaluation of Influence of Socio-economic Factors on Utilization of Selected Information and Communication Technologies for Extension Training among Extension Agents of Southwestern States, Nigeria
}

\author{
${ }^{1}$ Akintonde J.O., ${ }^{2}$ Akinola J.O., ${ }^{1}$ Akintaro O.S., ${ }^{1}$ Oladipo S.O., ${ }^{1}$ Oladosu I.O. and ${ }^{1}$ Ogunwale A.B. \\ ${ }^{1}$ Department of Agricultural Extension and Rural Development, PMB 4000, Ladoke Akintola University of Technology, Ogbomoso, Oyo State, \\ Nigeria. \\ ${ }^{2}$ Olusegun Oke Library, PMB 4000, Ladoke Akintola University of Technology, Ogbomoso, Oyo State, Nigeria.
}

DOI: 10.29322/IJSRP.11.09.2021.p11741

http://dx.doi.org/10.29322/IJSRP.11.09.2021.p11741

\begin{abstract}
The relevance of ICT to agricultural production cannot be over emphasized. Its application has leads to drastic increase in the level of food production among crop farmers as a result of their constant exposure to extension training on improved production technologies through the extension agents via different ICTs. This study therefore evaluated the influence of socio-economic factors on utilization of selected ICTs for extension training among extension agents of Southwestern States, Nigeria. Those factors influencing ICTs utilization were identified. Multistage sampling technique was employed to select Two-hundred and Eighty-seven EAs for the study. Data was collected with structured questionnaire and was analyzed with both descriptive and inferential statistical tools. The study revealed that majority (90.6\%) of the EAs in the extension service are males with only 9.4\% females and between age range of 31-40years and different educational background and years of experience. The study further identified CD/DVD player (78.4\%), GSM-phone (100.0\%), projector (77.1\%), Digital camera (45.6\%) as part of the ICTs used among EAs in the area. ICT skills $\left(\mathrm{WMS}=251 ; 1^{\text {st }}\right)$ and computer knowledge (WMS $=2.41 ; 2^{\text {nd }}$ ), possession/ownership status of ICTs $\left(\mathrm{WMS}=2.26 ; 3^{\text {rd }}\right.$ ) were ranked high as part of the identified factors that influence utilization of ICTs among the EAs. The years of working experience, sex, marital status and religion exhibited significant relationship with the utilization of selected ICTs for extension training. The study therefore, recommends that extension recruitment exercise should consider socio-economic factors of applicants in employing and deploying extension personnel for extension service; and extension agency should make extension service convenient for EAs through the provision of necessary supports and required ICTs for the extension training in order to encourage understanding and appropriate application of extension recommendations among the crop farmers in the area and Nigeria at large.
\end{abstract}

Index Terms- Influence, Socio-economic factor, ICT, Utilization, Extension Agent/Training

\section{INTRODUCTION}

$\mathrm{T}$ he recent growth experienced in agricultural sector associated with Information and Communication Technologies (ICTs). The application of ICT to agricultural is now pronounced and it has influence agricultural production among smallholder farmers across the country, especially in Southwestern part of Nigeria where most farmers owns a personal mobile phone to themselves, which facilitate dissemination of information among stakeholders in the agricultural sector. ICTs as a range of electronic technologies which when converged in new configurations are flexible, adaptable, enabling and capable of transforming organizations and redefining social relations. The range of technologies is increasing all the time and there is convergence between the new and the old media. The new media are computers, mobile phones and the internet, while the old media include radio, television, telephone, newspapers and extension bulletins among others (Chapman and Slaymaker, 2002). It also includes contemporary social networking aspects, read/write interfaces on the Web; besides file sharing systems online. It represents a broad and continually evolving range of elements that further includes the television (TV), radio, mobile phones and the policies and laws that govern the widespread use of these media and devices.

The term is often used in plural form (ICTs) to mean a range of technologies instead of a single technology (Balaji et al., 2007). The potential application of ICTs to extension work include: capacity to reach a large audience through the use of radio, television and Internet. It helps to facilitate training in order to encourage clear understanding and possible demonstrations to farmers which would ensure appropriate application of knowledge gained during extension training sessions. If modern ICT facilities are not adequately built into the main stream of Nigerian agricultural system, there is likely to be stagnation in the dissemination, utilization and application of scientific agricultural information for purposeful development of the system (Adebayo and Adesope, 2007). Arokoyo (2003) reports that in Nigeria, the national extension service is based on the witnessed an unprecedented growth in the area of ICT (Hosseini etal., 2009a). In spite of the rapid improvement in information and 
communication brought about in recent times, by science and technology, most of the extension workers in Nigeria and the Southwest region in particular, still rely on the approach of Training and Visit extension system.

Majority of the population in the developing world live in rural areas and has little or no access to agricultural information Hosseini et al., 2009b). The use of conventional communication channels such as farm/home visit, personal letters, and use of contact farmers, for disseminating agricultural information have been counterproductive. This calls for the adoption of ICTs by both researchers and extension workers to transmit relevant information to farmers in an efficient way (Salau and Saingbe, 2008). The use of ICT required some level of understanding, computer skill of the extension agent, appropriate application of ICTs for extension training. The study therefore pursues to evaluate the influence of socio-economic factors on the utilization of selected ICTs for extension training among the Extension Agents (EAs) of Southwestern States, Nigeria. Specifically, the study described the socio-economic variables of the EAs; identified the ICTs used by the EAs for extension training; determined the level of influence of the identified factors associated with the utilization of ICTs among the sampled EAs. The study tested for significant relationship between both the dependent and independent socio-economic variables.

\section{METHODOLOGY}

The study was carried out in Ogun and Oyo of South-West States of Nigeria. The South-West States lies between latitude $6.00^{\circ} \mathrm{N}$ and $9.00^{\circ} \mathrm{N}$ and between longitude $2.00^{\circ} \mathrm{E}$ and $7.00^{\circ} \mathrm{E}$. The area comprises six States namely: Ekiti, Lagos, Ogun, Ondo, Osun and Oyo. They collectively cover $114.271 \mathrm{~km} 2$, approximately $12 \%$ of Nigeria's total area. The capital Oyo State is Ibadan, the most populous city in black Africa with population of 5,591,589 (Census, 2006). Ogun State on the other hand is also a State in South-West, Nigeria. The State's nickname is "Gateway State". It was created on February $3^{\text {rd }}, 1976$ from the former Western State. The 2006 census recorded a total population of 3,751,140 with land area of $16,980.55 \mathrm{~km}^{2}$. The climate in the two States favours the cultivation of crops like maize, yam, cassava, millet, rice, plantains, cocoa, palm produce, cashew etc (Ogun State Wikipedia, the free encyclopedia.htm). These two States have not relented efforts in the development of agriculture which is usually achieved through the Agricultural Development Project under ministry of agriculture. Oyo State Agricultural Development Project (OYSADEP) made up of four Agricultural zones namely; Ogbomoso zone, Ibadan/Ibarapa zone, Saki zone and Oyo zone respectively. Likewise, Ogun State Agricultural Development Project (OGADEP) comprises of four Agricultural zones which include Abeokuta zone, Ijebu-ode zone, Ilaro zone and Ikenne zone. Multistage sampling technique was employed to select Two hundred and eighty-seven (287) EAs in both States, structured interview schedule was used to obtained relevant information from the sampled EAs. Both descriptive (frequency counts, percentages, mean and ranking) and inferential tools (Spearman rho and Chi-square) were used to analyzed the data of the study.

\section{RESULTS AND DISCUSSION}

\section{Socio-Economic Characteristics}

Based on the results of the analysis, the study revealed that more than half $(58.3 \%$; $57.5 \%)$ of the Extension Agents (EAs) sampled in Ogun and Oyo States were between the age distribution of 31-40 years, while their mean age was 37.84 years (Ogun) and 38.50 years (Oyo) respectively. The pooled percentage was $57.5 \%$ with the pooled mean of 38.25 years. The result implies that the EAs in the selected States were of different age distribution. With this mean age, it suggests that they are young and not too old which is expected to influence the utilization of different ICTs in training farmers on different extension training activities in the States. The result further shows that most $(85.2 \%$ and $93.9 \%)$ of the EAs sampled from Ogun and Oyo States were male, and that of pooled was $90.6 \%$, while only $14.8 \%$, and $6.1 \%$ were female in both Ogun and Oyo States. This result suggests that both genders constituted workforce of village extension unit. Majority $(99.1 \%$ and $98.9 \%$ ) of the EAs in both States were married and only $0.9 \%$ and $1.1 \%$ were single.

By implications, majority of the EAs in both Ogun and Oyo States are married. This status is expected to have influence on their job performance and professionalism especially in the utilization of ICTs in disseminating agricultural information to farmers in those States. The result also revealed most $(80.6 \%$ and $78.8 \%$ ) were Christian, while $19.6 \%$ and $21.8 \%$ Muslim from both Ogun and Oyo States (Table1). This implies that both religions formed the population of the EAs in the States. The religion affiliation may have influence on the utilization of identified ICTs among the EAs in both Ogun and Oyo States. Table1 further revealed that, more than half $(57.4 \%$ and $62.0 \%)$ of the EAs in both States were first degree (BSC/B.Tech) holders, while equal proportion of $11.1 \%$ and $11.7 \%$ of the EAs holds Ordinary National Diploma (OND); $13.9 \%$ and $7.8 \%$ holds Higher National Diploma (HND). Again, $13.9 \%$ and $3.9 \%$ holds National Certificate of Education (NCE); while $3.7 \%$ and $14.5 \%$ were master degree holders in both Ogun and Oyo States. This implies that all the EAs in the two States (Ogun and Oyo) holds different educational qualifications. The educational qualifications of the EAs is expected to have influence on the usage of ICTs in training farmers on different production techniques.

Table1 also reveals that $36.1 \%$ and $35.2 \%$ EAs have between less and equal to 5 years of working experience in extension services, $38.9 \%$ and $40.8 \%$ of EAs in both Ogun and Oyo States indicated 6-10 years of working experience, $13.9 \%$ and $15.6 \%$ indicated 11-15 years respectively as years of working experience in extension service as at the time when the data for this study was collected. The mean years of working experience of the EAs of both States were 8.28years and 8.03years with the Pooled of 8.13 years. The results suggest that all the EAs sampled are not novice in the extension service. Their years of working experience is expected to have influence the use of ICTs in training farmers on extension recommendations. Therefore, all the above socio-economic variables could be factors that may influence the utilization of ICTs among the EAs in training farmers on farming production techniques. 
Table1: Distribution of Respondents by Socio-Economic Factors

\begin{tabular}{|lccc|}
\hline Frequency (Percentage) & & \\
\hline Socio-economic variables & Ogun $(\mathbf{n}=\mathbf{1 0 8})$ & Oyo $(\mathbf{n}=\mathbf{1 7 9})$ & Pooled $(\mathbf{n}=\mathbf{2 8 7})$ \\
\hline Age (years) & & & \\
$\leq 3015(13.90)$ & $18(10.0)$ & $33(11.5)$ & $51(17.8)$ \\
$31-40$ & $63(58.3)$ & $102(57.0)$ & $165(57.5)$ \\
$41-50$ & $23(21.3)$ & $47(26.3)$ & $70(24.4)$ \\
Above 50 & $7(6.50)$ & $12(6.7)$ & $19(6.60)$ \\
\hline Sex & & \\
Male & $92(85.2)$ & $167(93.9)$ & $260(90.6)$ \\
Female & $16(14.8)$ & $11(6.1)$ & $27(9.40)$ \\
\hline Marital status & & \\
Married & $107(99.1)$ & $177(98.9)$ & $284(99.0)$ \\
Never married & $1(0.9)$ & $2(1.1)$ & $3(1.0)$ \\
\hline Religion & & \\
Christianity & $87(80.4)$ & $140(78.2)$ & $260(90.6)$ \\
Islam & $21(19.6)$ & $39(21.8)$ & $60(20.9)$ \\
\hline Educational Level & & \\
OND/HND/NCE & $42(38.9)$ & $40(22.4)$ & $84(29.2)$ \\
BSc/B.Tech & $62(57.4)$ & $111(62.1)$ & $173(60.3)$ \\
MSc/M.Tech4 & $(3.70)$ & $26(14.5)$ & $30(10.5)$ \\
\hline Years of experience in extension service & & \\
$\leq 5$ 39 & $39(38.9)$ & $63(35.2)$ & $102(35.5)$ \\
5-10 & $42(38.9)$ & $73(40.8)$ & $115(40.1)$ \\
Above 10 & $27(25.0)$ & $70(24.4)$ \\
Mean: & 5.96 & 6.10 \\
\hline
\end{tabular}

Source: Field Survey, 2013

Figures in parentheses are percentages

ICTs used by the EAs for extension training

Table2 reveals different ICTs used by the EAs for extension/farmers training and most $(83.3 \%$ and $75.4 \%)$ of the selected EAs in Ogun and Oyo States indicated CD/DVD player. Again, more than half $(69.4 \%$ and $61.5 \%)$ of the EAs indicated CD-ROM; $58.3 \% / 38.0 \%$ indicated camera. Also $37.0 \%$ and $48.0 \%$ indicated projector, while $18.5 \%$ and $20.7 \%$ indicated flash drive. Interestingly, all (100.0\%) of the EAs in both Ogun and Oyo States indicated GSM-phone; and 68.55/82.7\% indicated internet as part of the ICTs used among the EAs for extension/farmers training. The result implies that mobile phone is commonly used among the selected EAs in the two States. The result also implies that all the respondents used one type of ICT or the other for extension training in both Ogun and Oyo States. The variation in the type of ICT commonly used by the EAs may be due to differences in their ICT knowledge and skill, the nature of their clients and the type of relationship that exists between the extension agents and their clients especially when it comes to the use of GSM-phone for disseminating information on improved farm techniques. Again, this may be true because of the fact that majority of Nigeria farmers have personal GSM-phone, which encourage the mutual communication between the farmers and extension agents.

Table2: Distribution of respondents by ICT facilities used by Extension Agents

\begin{tabular}{|c|c|c|c|}
\hline \multicolumn{4}{|c|}{ *Frequency (Percentage) } \\
\hline ICT facilities used & $\operatorname{Ogun}(n=108)$ & Oуо $(n=179)$ & Pooled $(n=287)$ \\
\hline CD/DVD Player & $90(83.3)$ & $135(75.4)$ & $225(78.4)$ \\
\hline CD-ROM & $75(69.4)$ & $110(61.5)$ & $185(64.5)$ \\
\hline Digital camera & $63(58.3)$ & $68(38.0)$ & $131(45.6)$ \\
\hline Projector & $40(37.0)$ & $86(48.0)$ & $126(43.9)$ \\
\hline Flash drive & $20(18.5)$ & $37(20.7)$ & $57(19.9)$ \\
\hline GSM-phone & $108(100.0)$ & $179(100.0)$ & 287(100.0) \\
\hline Internet & $74(68.5)$ & $148(82.7)$ & $222(77.4)$ \\
\hline
\end{tabular}

Source: Field Survey, 2013

Figures in parentheses are percentages

*Multiple responses 
Associated factors/level of influence on the utilization of ICTs among the EAs

For this objective, three level rating scale of high, moderate and low were used to determine the level of use of ICTs among the sampled EAs. Thereafter, statistical mean was computed and the identified associated factors were ranked accordingly. The result in Table 2 therefore revealed that ICTs skill level had the highest weighted mean score (WMS) of 2.51 and therefore ranked first $\left(1^{\text {st }}\right)$, followed by Computer knowledge of EAs (WMS=2.41; $\left.2^{\text {nd }}\right)$ and possession/ownership status of ICTs $\left(\mathrm{WMS}=2.26 ; 3^{\text {rd }}\right)$,
Constant power supply (WMS $\left.=2.25 ; 4^{\text {th }}\right)$ / availability of agricultural technologies (WMS $\left.=2.25 ; 4^{\text {th }}\right)$. Availability of ICTs (WMS $=2.20)$, literacy level of farmers (clientele) (WMS=2.17), proximity to ICT centres $(\mathrm{WMS}=2.16)$ were ranked $6^{\text {th }}, 7^{\text {th }}$ and $8^{\text {th }}$ respectively. However, participation of farmers in the creation of content/selection of ICTs for extension training was ranked least $\left(\mathrm{WMS}=2.02 ; 10^{\text {th }}\right)$. This result implies that each identified factor has contribution to the usage of different ICTs for training of farmers on improved production technologies or methods.

Table3: Distribution of respondents by level of influence of identified factors associated with the utilization of ICTs among Extension Agents

\begin{tabular}{|c|c|c|c|c|c|}
\hline \multirow{3}{*}{ Factors } & \multicolumn{5}{|c|}{ Frequency (Percentages) } \\
\hline & \multicolumn{5}{|c|}{ Level of influence } \\
\hline & High & Moderate & Low & WMS & Rank \\
\hline Availability of agric. Technologies & $119(41.5)$ & $121(42.2)$ & $47(16.4)$ & 2.25 & 4th \\
\hline Computer knowledge & $143(49.8)$ & $119(41.5)$ & $25(8.7)$ & 2.41 & 2nd \\
\hline Availability of ICTs & $105(36.6)$ & $85(12.2)$ & $147(51.2)$ & 2.85 & 6th \\
\hline ICTs skills & $177(61.7)$ & $80(27.9)$ & $30(10.5)$ & 2.51 & $1 \mathrm{st}$ \\
\hline Possessing/ownership status of ICT & $131(45.6)$ & 101(35.2) & $55(19.1)$ & 2.26 & $3 \mathrm{rd}$ \\
\hline Constant power supply & $116(40.4)$ & $127(44.3)$ & $44(15.4)$ & 2.25 & 4th \\
\hline Proximity to ICT centre & $135(47.0)$ & $63(22.0)$ & $89(31.0)$ & 2.16 & 8th \\
\hline Information on ICTs & $100(34.8)$ & 114(39.7) & $73(25.4)$ & 2.09 & 9th \\
\hline $\begin{array}{l}\text { Participation of farmers in the creation of } \\
\text { content/selection of ICTs selection of ICT }\end{array}$ & $77+2>$ & $128(481)$ & $72(251)$ & 200 & 10th \\
\hline Literacy level of farmers & $90(31.4)$ & $155(54.0)$ & $42(14.7)$ & 2.17 & 7 th \\
\hline
\end{tabular}

\section{Source: Field Survey, 2013}

Figures in parentheses are percentages

\section{WMS: Weighted Mean Score}

Test of significant relationship between variables

Each of the independent variable was attached against the dependent variable. The significance of relationship was determined at 0.05 level of significance. Two inferential tools (spearman's rho and Chi-square) were used for the test. The Spearman's rho was used where the variables were measured at interval level and Chi-square was used for variables that were measured at nominal and ordinal levels. Considering the pooled result in Table4a reveals that only years of working experience ( $r=$ $0.732 * *, p<0.05$ ) of EAs in extension service exhited a significant relationship with the utilization of selected ICTs for extension training. This implies that the higher the years spent in extension service, the higher the tendency to influence the utilization of ICTs for extension training among the EAs.

The result of Chi-square analysis in Table $4 \mathrm{~b}$ also revealed that there is a significant relationship between the EAs' sex, marital status, and religion and utilization of selected ICTs for extension training in both Ogun and Oyo States. This result implies that all the aforementioned socio-economic variables (years of working experience, sex, age and religion of the EAs have decisive influence on the utilization of ICTs for extension/farmers training.

Table4a: Result of Spearman's rho analysis showing significant relationship between selected socio-economic variables of EAs and level of influence of ICTs for extension training

\begin{tabular}{|l|l|l|l|}
\hline Socio-economic variables & \multicolumn{2}{|l|}{ Correlation coefficient } \\
\cline { 2 - 4 } & Ogun State & Oyo State & Pooled result \\
\hline Years spent in school & 0.083 & 1.000 & 1.000 \\
Academic qualification & 0.098 & -0.055 & -0.057 \\
Attendance of training on ICTs & -0.056 & -0.067 & -0.092 \\
Years of experience in extension service & 0.045 & $0.718^{* *}$ & $-0.732^{* *}$ \\
Years of experience in ICTs usage & 1.000 & 0.116 & 0.101 \\
& & & \\
& & & \\
\hline
\end{tabular}


Source: Data Analysis, 2013

**: Correlation is significant at 0.01 level (2-tailed)

Table4b: Chi-square analysis showing significant relationship between selected socio-economic characteristics of extension agents and utilization of ICTs

\begin{tabular}{|c|c|c|c|c|c|c|c|c|c|}
\hline Variable & \multicolumn{3}{|l|}{$\mathrm{X}^{2}$ - Cal } & \multicolumn{3}{|l|}{ Df } & \multicolumn{3}{|c|}{$\mathrm{X}^{2}-\mathrm{Tab}$} \\
\hline & Ogun & Oyo & Pooled & Ogun & Oyo & Pooled & Ogun & Oуо & Pooled \\
\hline Sex & 35.593 & 42.285 & 77.355 & 1 & 1 & 1 & 3.84 & 3.84 & 3.84 \\
\hline $\begin{array}{l}\text { Marital } \\
\text { Status }\end{array}$ & 104.037 & 171.089 & 275.125 & 1 & 1 & 1 & 3.84 & 3.84 & 3.84 \\
\hline Religion & 40.333 & 56.989 & 97.174 & 1 & 1 & 1 & 3.84 & 3.84 & 3.84 \\
\hline \multicolumn{3}{|l|}{ Result } & \multicolumn{4}{|l|}{ Decision } & & & \\
\hline Ogun & Oyo & Pooled & Ogun & Oyo & & Pooled & & & \\
\hline $\mathrm{S}$ & $S$ & $\mathrm{~S}$ & Reject $\mathrm{H} 0$ & Rejec & & Reject H0 & & & \\
\hline $\mathrm{S}$ & $S$ & $\mathrm{~S}$ & Reject H0 & Rejec & & Reject H0 & & & \\
\hline $\mathrm{S}$ & $\mathrm{S}$ & $\mathrm{S}$ & Reject H0 & Rejec & & Reject H0 & & & \\
\hline
\end{tabular}

Source: Data Analysis, 2013; Significant at 0.05 level

\section{CONCLUSION AND RECOMMENDATIONS}

This study evaluated the influence of socio-economic factors on the utilization of selected ICTs for extension training. The study revealed that EAs uses different ICT facilities for extension training in the area. ICTs skill, computer knowledge, possession/ownership status of ICT, constant power supply as well as availability of agricultural production technologies among others were rated differently with respect to their level of influence by the EAs. However, the study revealed that some of the socioeconomic variables such years of working experience, sex, marital status and religion have significant relationship with the level of influence of identified factors associated with the utilization of ICTs for extension training. The study therefore recommends that extension recruitment exercise should consider socio-economic factors of applicants in employing and deploying extension personnel for extension service; and extension agency should make extension service convenient for EAs through the provision of necessary supports and required ICTs for the extension training in order to encourage understanding and appropriate application of extension recommendations among the crop farmers in the area and Nigeria at large.

\section{REFERENCES}

[1] Adebayo, E.L. and Adesope, O.M. (2007). Awareness, access and usage of information and communication technologies between female researchers and extensionists. Int. J. Edu. Dev. using ICT, 3(1):85-93.

[2] Arokoyo, T. (2005). ICTs Application in Agricultural Extension Delivery. In Adedoyin S.F. (ed). Agricultural Extension in Nigeria. 1st edition. Ilorin: AESON, pp245-251.

[3] Balaji, V., Meera, S.N. and Dixit, S. (2007). ICT- enabled knowledge sharing in support of extension: addressing the agrarian challenges of the developing world threaten by climate change, with a case study from India, 4(1):1-18.

[4] Hossein, S.F.J., Niknami, M. and Nejad, G.H.H. (2009b). Policies Affecting the Application of Information and Communication Technologies by Agricultural Extension Service. Am. J. Appl. Sci. 6 (8): 1478-1483.
[5] Hosseini, S.J.F., Niknami, M. and Chizari, M. (2009a). To determine the challenges in the application of ICTs by the agricultural extension service in Iran, J. Agric. Ext. Rural Dev., 1(1):27-30.

[6] Salau, E.S. and Saingbe, N.D. (2008). Access and Utilization of Information and Communication Technologies (ICTs) Among Agricultural Researchers and Extension Workers in Selected Institutions in Nasarawa StateofNigeria.4(2): 1-11.

[7] Chapman, R. and T. Slaymaker (2002): ICT and Rural Development: Review of Literature, Current Interventions and Opportunities for Action, Overseas Development Institute (ODI), working paper 192.

\section{AUTHORS}

First Author - Akintonde J.O, Department of Agricultural Extension and Rural Development, PMB 4000, Ladoke Akintola University of Technology, Ogbomoso, Oyo State, Nigeria. Second Author - Akinola J.O., Olusegun Oke Library, PMB 4000, Ladoke Akintola University of Technology, Ogbomoso, Oyo State, Nigeria.

Third Author - Akintaro O.S, Department of Agricultural Extension and Rural Development, PMB 4000, Ladoke Akintola University of Technology, Ogbomoso, Oyo State, Nigeria. Fourth Author - Oladipo S.O, Department of Agricultural Extension and Rural Development, PMB 4000, Ladoke Akintola University of Technology, Ogbomoso, Oyo State, Nigeria. Fifth Author - Oladosu I.O, Department of Agricultural Extension and Rural Development, PMB 4000, Ladoke Akintola University of Technology, Ogbomoso, Oyo State, Nigeria. Sixth Author - Ogunwale A.B., Department of Agricultural Extension and Rural Development, PMB 4000, Ladoke Akintola University of Technology, Ogbomoso, Oyo State, Nigeria.

Correspondence: joakintonde@ lautech.edu.ng and joakinola@lautech.edu.ng 
International Journal of Scientific and Research Publications, Volume 11, Issue 9, September 2021

This publication is licensed under Creative Commons Attribution CC BY. 